\title{
AN EXPERIMENTAL AND MODELING INVESTIGATION ON DRYING OF CHICKEN MEAT IN CONVECTIVE DRYER
}

\author{
OSMAN ISMAIL
}

\begin{abstract}
This work reported a theoretical and experimental study on the thin layer drying kinetics of chicken meat samples under different air drying conditions. Experimental drying curves of chicken meat were performed under different drying air conditions (three air temperatures: 40,50 and $60{ }^{\circ} \mathrm{C}$, air velocities: $1 \mathrm{~ms}^{-1}$, and at atmosphere humidity). The drying rate was found to increase significantly with increase in temperature. The duration of constant rate period was found to be insignificant considering the total duration of drying and the entire drying period was considered to follow falling rate period. The experimental moisture ratio data was fitted to eight thin layer drying models. The Midilli et al. model showed the best fit in all drying conditions. The effective moisture diffusivity has been found to be varying between $4.39 \times 10^{-10}$ and $9.96 \times 10^{-10} \mathrm{~m}^{2} \mathrm{~s}^{-1}$ and activation energy was $27.85 \mathrm{~kJ} \mathrm{~mol}^{-1}$.
\end{abstract}

Keywords: Chicken meat, mathematical modeling, diffusion, activation energy

\section{INTRODUCTION}

Increasing life standards impose people to change their eating habits and promote them to consume. With population growth and increasing income, the consumption of meat is expected to grow by $73 \%$ by 2050 [1]. U.S. Department of Agriculture (USDA) statistical data showed that the production of chicken meat world-wide is about 84 million tons; the major producer countries are USA, China, Brazil, European union etc. and Turkey. Turkey produced 1.7 million tons in 2013 [2]. From a nutritional perspective, chicken consists of high-quality protein (that is, protein that contains the eight essential amino acids), low in cholesterol and a relatively

\footnotetext{
a* Yildiz Technical University, Davutpasa Campus, Faculty of Chemical and Metallurgical Engineering, Department of Chemical Engineering, Davutpasa , 34210 Esenler, Istanbul, Turkey. E-mail: ismail@yildiz.edu.tr
} 
low amount of fat. Thus, chicken is often recommended by physicians and nutrition counselors as an alternative to red meat [3].

It is seen that the amount of meat production and consumption is associated with a special occasion and meat is consumed in large quantity for a limited period. The excess meat should be preserved for future consumption. A major problem associated with traditional or sun drying of meat is the infestation of the product by the fly and insect larvae during drying and storage and products are deteriorated before consumption. Recently some drying techniques have been developed to prevent this. One of these techniques is the convection drying method. Hot air drying is widely used for centuries to preserve food products and it allows their availability regardless the season of the year [4].

Drying is one of the oldest food preservation methods for decreasing available water in food materials and increasing shelf life of foods. In other words, drying of meat or any food material reduces the availability of water in meat and thus also water activity to a level where microbes cannot survive and thus meat is preserved. Moreover, volume and weight of the product decreases significantly resulting in lower costs and making easy the transport and the storage of the dried products comparing to the fresh ones [5] This process involves simultaneous heat and mass transfer, however due to the complexity of this process, some researchers developed semi-theoretical and empirical models derived from Fickian diffusion approach to explain the water movement within the solid food materials [6]. The semi-theoretical and empirical models have been applied and found best at describing the drying process and predicting the drying kinetics of numerous agricultural foods. Thin layer convective hot air drying technique enables the effective control and uniform distribution of drying air and temperature conditions over the material, thereby improving the overall quality of the final product. Decreasing the relative humidity and increasing the drying temperature is a potential way of shortening the process of producing dry cured meat products [7] and has been successfully applied to shorten the drying period of raw and cooked chicken meats [8].

Knowledge of the drying kinetics is essential for a good modeling of the drying process. Some studies have been conducted on the drying kinetics of chicken meat [7-9] which have mainly covered the effect of the drying air parameters and the modeling of this kinetics.

The objectives of this study, is to determine the drying mechanism of chicken meat with increasing drying temperature. Also thin layer drying modeling of the drying process to predict and simulate the drying behavior of chicken meat has been studied. For this purpose, eight different thin layer drying models were fitted to experimental drying data and applicability 
of the models was compared according to statistical parameters. In addition, the diffusion coefficient and the activation energy of the samples were also calculated.

\section{RESULT AND DISCUSSION}

\section{Chemical composition of fresh chicken meat samples}

Initial moisture content, protein, fat and ash were determined using the method of AOAC [10]. The initial moisture content, ash, protein and fat percentage of fresh chicken meat samples are shown in Table 1.

Table 1. Composition of the fresh chicken samples

\begin{tabular}{|l|c|c|c|}
\hline Moisture content & Protein & Fat & Ash \\
\hline $73.96 \pm 0.04$ & $22.38 \pm 0.16$ & $2.39 \pm 0.15$ & $1.22 \pm 0.04$ \\
\hline
\end{tabular}

The initial moisture content and dry matter were $73.96 \%$ and $26.04 \%$ respectively. As seen from the table, protein is the major component of chicken samples other than water. The protein, fat and ash content of chicken samples was $22.38 \%, 2.39 \%$ and $1.22 \%$, respectively. Our findings are consistent with the literature in which it was reported that chicken meat tissue consists of approximately $74.71 \%$ water, $25.29 \%$ dry matter, $21.86 \%$ protein, $1.75 \%$ fat and $1.13 \%$ ash [11].

\section{Drying curves}

Drying rates $(D R)$ were determined by using the forward finite difference method according to Equation 1 [8].

$$
D R=\frac{M_{t+\Delta t}-M_{t}}{\Delta t}
$$

where: $M_{t+\Delta t}$ is the moisture content of samples at $t+\Delta t$ ( $\left.g_{\text {water }} / g_{\text {dry matter }}\right), t$ is the time (min).

Drying rate is defined as the amount of water removed and time is shown in Figure 1 for chicken samples during thin layer drying at 40, 50 and $60{ }^{\circ} \mathrm{C}$. 


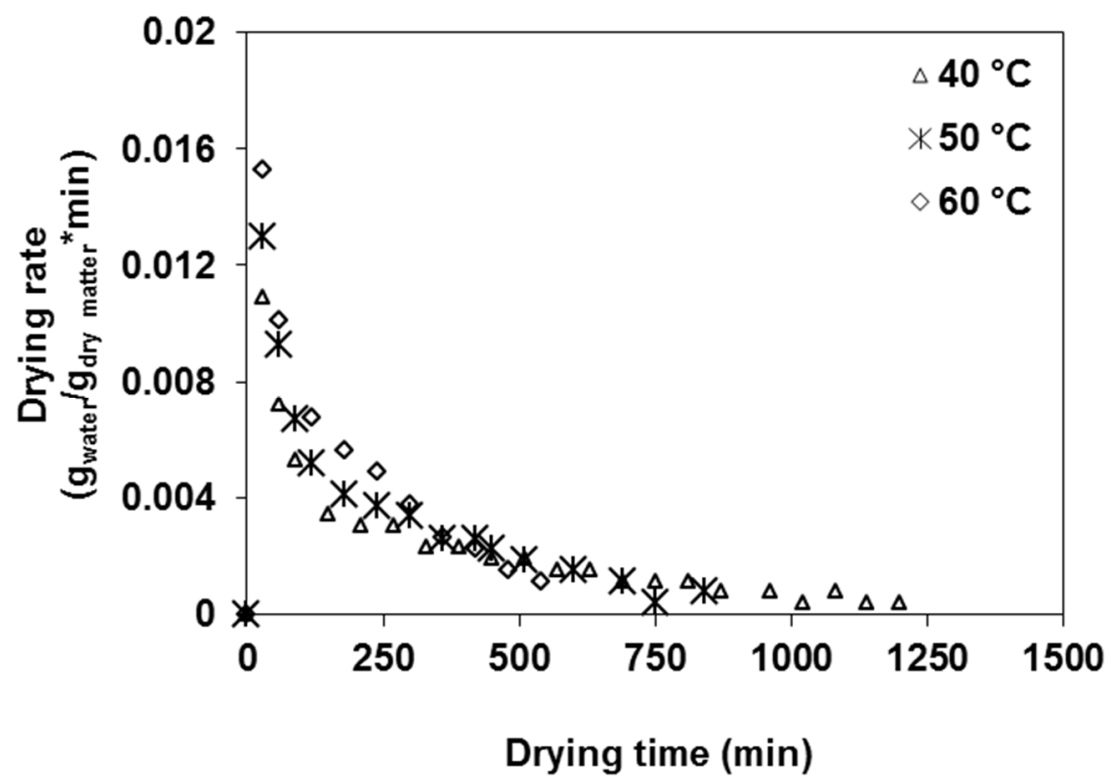

Figure 1. Variation of drying rate with drying time of chicken meat samples at different temperatures

\section{Modelling of the thin-layer drying characteristics}

The experimental drying data resulting from hot-air drying of chicken samples at different temperatures were fitted to eight different thin-layer drying models shown in Table 2.

Table 2. Mathematical models for drying curves

\begin{tabular}{|l|l|c|}
\hline \multicolumn{1}{|c|}{ Model Name } & \multicolumn{1}{c|}{ Equation } & Reference \\
\hline Newton & $M R=\exp (-k t)$ & {$[14]$} \\
\hline Page & $M R=\exp \left(-k t^{n}\right)$ & {$[14]$} \\
\hline Henderson and Pabis & $M R=a \exp (-k t)$ & {$[15]$} \\
\hline Logarithmic & $M R=a \exp (-k t)+b$ & {$[11]$} \\
\hline Aghbashlo et al. & $M R=\exp \left(\left(-k_{1} t\right) /\left(1+k_{2} t\right)\right)$ & {$[16]$} \\
\hline Wang and Singh & $M R=1+b t+a t^{2}$ & {$[11]$} \\
\hline Midilli et al. & $M R=a \exp \left(-k t^{n}\right)+b t$ & {$[17]$} \\
\hline Alibas & $M R=a \exp \left(\left(-k t^{n}\right)+b t\right)+g$ & {$[18]$} \\
\hline
\end{tabular}


The moisture content of a drying sample at any time $\mathrm{t}$ can be expressed as moisture ratio $(M R)$ as follows:

$$
M R=\frac{M_{t}-M e}{M_{0}-M_{e}}
$$

where: $M_{t}, M_{e}$ and $M_{0}$ are the moisture content at selected time, at equilibrium and the initial value in $\mathrm{g}_{\text {water }} / \mathrm{g}_{\text {dry matter }}$.

The obtained drying data was evaluated using nonlinear least squares regression analysis. The regression anlaysis was performed using the 6.0 program software (Statsoft Inc., Tulsa, OK) computer program. The correlation coeficient $\left(R^{2}\right)$, reduced chi-square $\left(\chi^{2}\right)$ and root mean square error (RMSE) were used as the primary criteria for selection of the best model to define the drying curves [19]. These statistical values can be determined using the following equations:

$$
\begin{gathered}
\mathrm{RMSE}=\left[\frac{1}{\mathrm{~N}_{\mathrm{i}=1}}{ }_{\Sigma=1}^{\mathrm{N}}\left(\mathrm{MR}_{\text {pre }, \mathrm{i}}-\mathrm{MR}_{\exp , \mathrm{i}}\right)^{2}\right]^{1 / 2} \\
\chi^{2}=\frac{{ }_{\Sigma}^{\mathrm{N}=1}\left(\mathrm{MR}_{\exp , \mathrm{i}}-\mathrm{MR}_{\text {pre }, \mathrm{i}}\right)^{2}}{\mathrm{~N}-\mathrm{Z}}
\end{gathered}
$$

where $M R_{\text {exp }}$ and $M R_{\text {pre }}$ represent experimental and predicted values of moisture ratios, respectively. $N$ is the total number of experiments, and $z$ is the number of constants in the drying model. The best model was selected with based on the highest $R^{2}$ and the lowest $X^{2}$, and the lowest RMSE values. The curve fitting criteria or statistical calculation results for these models are shown in Table 3.

As seen from the tables, $R^{2}$ values higher than 0.98 indicating a good fit since $R^{2}$ value close to unity implies that the predicted drying data is close to the experimental drying data. This means that all established models successfully described the relation between time and MR. Another statistical parameters calculated to compare the model's accuracy were $X 2$ and $R M S E$ values, which represent the differences between the predicted and experimental values. Therefore, the fact that $X^{2}$ and RMSE values are close to zero is desired. Among the thin-layer drying models, the Midilli et al. model was found to represent the drying kinetics of chicken samples with high $R^{2}$ values and low $X^{2}$ and $R M S E$ values for all temperatures. It is clear that the $R^{2}, X^{2}$ and $R M S E$ values of this model were changed between 0.9992 and $0.9998,0.000019$ and $0.000121,0.004006$ and 0.010466 , respectively. Variation of experimental 
and predicted moisture ratio by Midilli et al. model with drying time are shown in Figure 2. As can be observed in this figure, good agreement between the former variables is observed.

Table 3. Curve fitting criteria for the thin layer drying models for drying of chicken meat samples

\begin{tabular}{|c|c|c|c|c|}
\hline Models & $\begin{array}{l}\text { Drying temperature } \\
\left({ }^{\circ} \mathrm{C}\right)\end{array}$ & $R^{2}$ & $x^{2}$ & RMSE \\
\hline \multirow{3}{*}{ Newton } & 40 & 0.9987 & 0.000178 & 0.013191 \\
\hline & 50 & 0.9957 & 0.000596 & 0.023992 \\
\hline & 60 & 0.9954 & 0.000670 & 0.02519 \\
\hline \multirow{3}{*}{ Page } & 40 & 0.9988 & 0.000171 & 0.012762 \\
\hline & 50 & 0.9961 & 0.000549 & 0.022634 \\
\hline & 60 & 0.9972 & 0.000428 & 0.019563 \\
\hline \multirow{3}{*}{$\begin{array}{l}\text { Henderson } \\
\text { and Pabis }\end{array}$} & 40 & 0.9991 & 0.000128 & 0.011064 \\
\hline & 50 & 0.9967 & 0.000460 & 0.020721 \\
\hline & 60 & 0.9971 & 0.000438 & 0.019798 \\
\hline \multirow{3}{*}{ Logarithmic } & 40 & 0.9992 & 0.000128 & 0.010479 \\
\hline & 50 & 0.9980 & 0.000445 & 0.020012 \\
\hline & 60 & 0.9973 & 0.000443 & 0.019304 \\
\hline \multirow{3}{*}{$\begin{array}{l}\text { Aghbashlo } \\
\text { et al. }\end{array}$} & 40 & 0.9987 & 0.000182 & 0.013179 \\
\hline & 50 & 0.9957 & 0.000615 & 0.02395 \\
\hline & 60 & 0.9963 & 0.000573 & 0.022636 \\
\hline \multirow{3}{*}{$\begin{array}{l}\text { Wang and } \\
\text { Singh }\end{array}$} & 40 & 0.9904 & 0.001368 & 0.036114 \\
\hline & 50 & 0.9872 & 0.001816 & 0.041147 \\
\hline & 60 & 0.9834 & 0.002547 & 0.047728 \\
\hline \multirow{3}{*}{ Midilli et al. } & 40 & 0.9992 & 0.000121 & 0.010466 \\
\hline & 50 & 0.9998 & 0.000019 & 0.004006 \\
\hline & 60 & 0.9997 & 0.000041 & 0.005680 \\
\hline \multirow{3}{*}{ Alibas } & 40 & 0.9992 & 0.000124 & 0.010468 \\
\hline & 50 & 0.9998 & 0.000024 & 0.004539 \\
\hline & 60 & 0.9996 & 0.000073 & 0.007322 \\
\hline
\end{tabular}

As seen in Figure 2, chicken meat drying curves were obtained using a convective tray drier at different temperatures of 50,60 and $70{ }^{\circ} \mathrm{C}$ requiring of 1260,870 and $540 \mathrm{~min}$, respectively, to reach dry basis moisture content of about $14 \%$. 


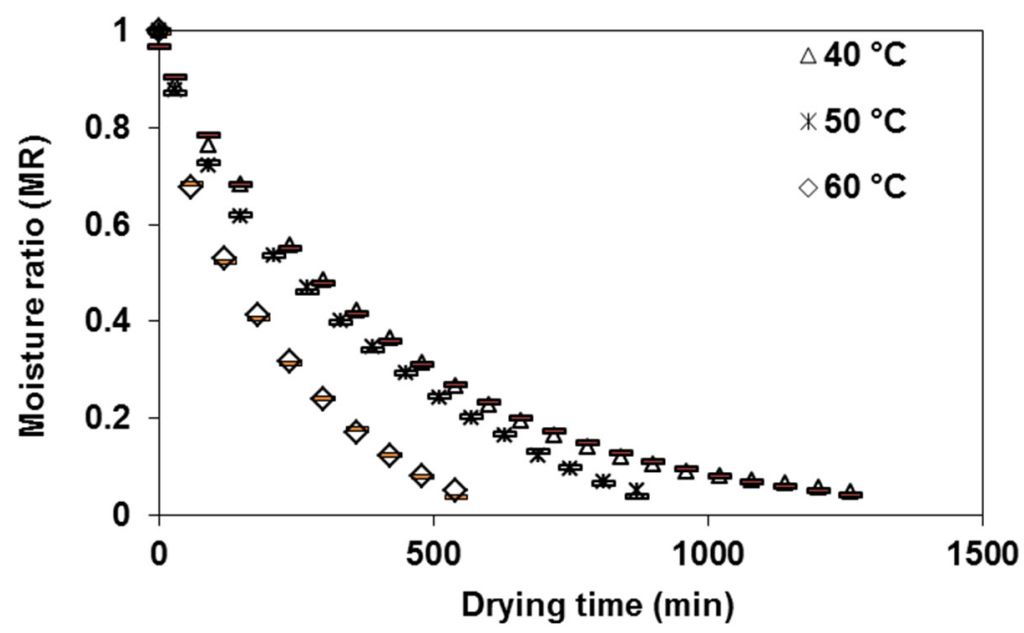

Figure 2. Variation of experimental and predicted moisture ratio by Midilli et al. model with drying time at different drying temperatures

\section{Determination of the effective moisture diffusivity and activation energy}

Effective moisture diffusivity $\left(D_{\text {eff }}\right)$ was determined according to the general solution of Fick's second law equation for slab geometry (where $L$ half thickness) in Equation 5 and only the first term of the equation was used [20].

$$
M R=\frac{M_{t}-M_{e}}{M_{0}-M_{e}}=\frac{8}{\pi^{2}} \exp \left[-\frac{\pi^{2} D_{\text {eff }} t}{4 L^{2}}\right]
$$

where, $D_{\text {eff }}$ is the effective moisture diffusivity $\left(\mathrm{m}^{2} / \mathrm{s}\right)$ and $L$ is the half thickness of chicken samples $(m)$.

The variation in In (MR) and drying time $(\mathrm{t})$ at different temperatures have been plotted to obtain the slope Equation 5 which can give the effective moisture diffusivity.

$$
S=\frac{\pi^{2} D_{\text {eff }}}{4 L^{2}}
$$

By the help of the slope Equation 6, effective moisture diffusivity of chicken meat samples were calculated and shown in Table 4. 
Table 4. Effective moisture diffusivity values for chicken meat samples at different temperatures

\begin{tabular}{|c|c|}
\hline Drying Temperature $\left({ }^{\circ} \mathbf{C}\right)$ & Effective moisture diffusivity $\left(\mathbf{m}^{2} / \mathbf{s}\right)$ \\
\hline 40 & $4.39 \times 10^{-10}$ \\
\hline 50 & $6.08 \times 10^{-10}$ \\
\hline 60 & $9.96 \times 10^{-10}$ \\
\hline
\end{tabular}

As seen in Table 4, it was observed that $D_{\text {eff }}$ values increased with increasing air temperature. This phenomenon might be due to the fact that effective moisture diffusivity $\left(D_{\text {eff }}\right)$ depends on the drying air temperature, cultivar, and composition of the drying samples [21]. The effective moisture diffusivity of chicken samples was $4.39 \times 10-10,6.08 \times 10^{-10}$ and $9.96 \times 10^{-10} \mathrm{~m}^{2} / \mathrm{s}$ at 40,50 and $60{ }^{\circ} \mathrm{C}$, respectively. $D_{\text {eff }}$ values for different food and agricultural products usually varied between $10^{-11}-10^{-9} \mathrm{~m}^{2} / \mathrm{s}$ [21].

The Arrhenius equation was developed to relate the effective moisture diffusivity values to temperatures Equation 7.

$$
D_{\text {eff }}=D_{o} \exp \left(-\frac{E_{a}}{R T}\right)
$$

where $D_{0}$ is the pre-exponential factor of Arrhenius equation or is the diffusivity for infinite temperature $\left(\mathrm{m}^{2} / \mathrm{s}\right), E_{a}$ is the activation energy $(\mathrm{J} / \mathrm{mol}), R$ is the gas constant $(8.31451 \mathrm{~J} / \mathrm{mol} \mathrm{K}$ ) and $T$ is the drying temperature (Kelvin).

Values of In $\left(D_{\text {eff }}\right)$ plotted against $1 /(T+273)$ for calculated activation energy are shown in Figure 3.

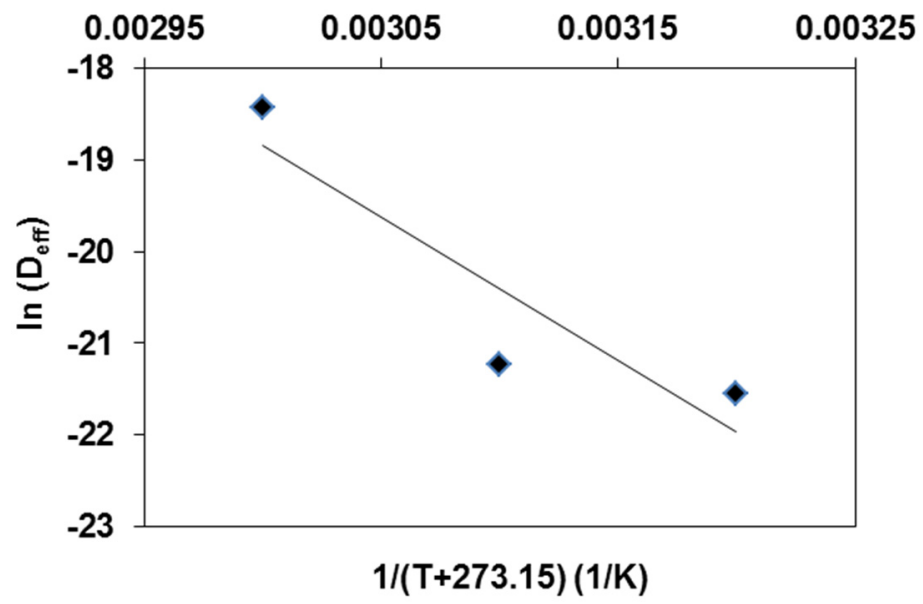

Figure 3. Arrhenius-type relationship between effective moisture diffusivity and temperature. 
The activation energy is a sign of the required energy to delete moisture from a solid matrix. Higher $E_{a}$ value indicates greatest temperature sensitivity of diffusion coefficient. The $E_{a}$ value for chicken meat samples was found 27.85 $\mathrm{kJ} / \mathrm{mol}$. The values of the activation energy lie from 12.7 to $110 \mathrm{~kJ} / \mathrm{mol}$ for most food materials [22]. Hii et al. [8] reported this value varying from 16.3 and $22.8 \mathrm{~kJ} / \mathrm{mol}$ for for the raw and cooked chicken meat samples.

\section{CONCLUSIONS}

In this study, thin layer drying kinetics of chicken meat was studied at drying air temperatures of 40,50 and $60^{\circ} \mathrm{C}$. In conclusion, drying of chicken meat in the convective dryer was only described by the falling rate period. Drying air temperature were influencing factor to drying kinetics. Both the drying rate and moisture ratio decreased with time. Effective moisture diffusivity increased with increasing air temperature, and varied from 4.39 to $9.96 \times 10^{-10} \mathrm{~m}^{2} / \mathrm{s}$ over the temperature range investigated, with activation energy equal to $27.85 \mathrm{~kJ} / \mathrm{mol}$. Eight selected thin layer drying models showed that the Midilli et al. model resulted in an excellent fit for all drying temperatures. These results clearly show that the Midilli et al. model was most suitable for predicting the drying curve of chicken meat. The Midilli et al. model was further validated by comparing the predicted moisture ratio against the experimental moisture figures. Therefore, the Midilli et al. model could be applied in describing the drying behavior and predicting the drying kinetics of chicken meat.

\section{EXPERIMENTAL SECTION}

\section{Sample preparation}

Chicken breast, used as raw material in the present study, was obtained from a butcher in Istanbul, Turkey. Chicken breast meat was obtained from the broiler chicks (Ross 308 ) at 45 days (Banvit A.Ş., Bandırma, Turkey). The chicken breasts were cut to a size of $6 \mathrm{~cm} \times 4 \mathrm{~cm} \times$ $1 \mathrm{~cm}(24 \pm 0.5 \mathrm{~g})$. In order to preserve its original quality, they were stored in a Arcelik 1050 model refrigerator (Arcelik, Eskisehir, Turkey) at $4{ }^{\circ} \mathrm{C}$ until drying experiments were conducted.

\section{Drying equipment and drying procedure}

Drying experiments were performed in a cabinet laboratory type dryer (API \& PASILAC Limited of Carlisle, Cambria, UK). In each experiment, 95 $2 \mathrm{~g}$ of chicken samples was used. The chicken meat samples, was uniformly spread in a square basket in a single layer after the desired drying conditions 
had stabilized. In order to prevent sticking and to facilitate easy removal of the sample after drying, the tray was lined with $80 \mu \mathrm{m}$ thick polyethylene sheet. The dryer was installed in an environment with the relative air humidity of about $40-50 \%$ and the ambient air temperature about $18-25{ }^{\circ} \mathrm{C}$. Drying experiments of chicken samples were conducted at three temperatures, 40 , 50 and $60{ }^{\circ} \mathrm{C}$, at a constant air velocity $(1.0 \mathrm{~m} / \mathrm{s})$. To record the moisture loss during drying the trays were taken out of the dryer at regular intervals, weighed at 30 minute intervals by using an Ohaus PA214C digital balance which has an accuracy of $0.001 \mathrm{~g}$ (Ohaus, NY, USA) and quickly replaced inside the dryer. It was assumed that brief interruptions (less than $20 \mathrm{~s}$ ) did not interfere with the drying process. The drying process was continued until the weight of the sample was reduced by the initial moisture content of about $0.14 \pm 0.03 \mathrm{~g}_{\text {water }} / \mathrm{g}_{\text {drymatter }}$ at air temperatures of 40,50 and $60^{\circ} \mathrm{C}$, respectively.

\section{Statistical analysis}

All experiments and analyzes were repeated three times and data sets were subjected to analysis of variance using the general linear models. Significant differences between the samples means were determined at the $p<0.05$ levels by ANOVA.

\section{REFERENCES}

1. FAO, Food and Agrıculture Organızatıon. Livestock in the balance Part 1. The state of food and agriculture report, 24, 2009.

2. USDA, U.S. Department of Agriculture, www.usda.gov Accessed Jun 24, 2014.

3. K.E. Charlton, Y.C. Probst, L.C. Tapsell, P.J. Blackhall, Journal of the Home Economics Institute of Australia, 2008, 15, 5.

4.X.D. Chen, A.S. Mujumdar, "Drying Technologies in Food Processing". Blackwell Publishing Ltd., Oxford, UK, 2008.

5. A.S. Mujumdar, S. Devahastin, "Fundamental principles of drying", In Devahastin (ed.), Mujumdar's Practical Guide to Industrial Drying, Exergex Corp., Montreal, Canada, 2000, pp. 1.

6. Z. Erbay, F. Icier, Critical Reviewers in Food Science and Nutrition, 2010, 50, 441.

7. J. Arnau, X. Serra, J. Comaposada, P. Gou, M. Garriga, Meat Science, 2007, $77,81$.

8. C.L. Hii, C.E. Itam, S.P. Ong, Drying Technology, 2014, 32, 1304.

9. H. Çakmak, S. Kumcuoğlu, Ş. Tavman, Gıda, 2014, 39, 131. 
10. AOAC, Official Methods of Analysis of AOAC International. 16th ed. Gaitherbury, Maryland, USA, 1998.

11. M. Başlar, M. Kılıçı, O.S. Toker, O. Sağdıç, M. Arici, Innovative Food Science and Emerging Technologies, 2014, 26, 182.

12. S. Nag, K.K. Dash, International Food Research Journal, 2016, 23, 2594.

13. P.S. Madamba, R.H. Driscoll, K.A. Buckle, Journal of Food Engineering, 1996, $29,75$.

14. T. Ahmat, M. Barka, A.W. Aregba, D. Bruneau, Journal of Food Processing and Preservation, 2015, 39, 2581.

15. S.M. Henderson, S. Pabis, Journal of Agricultural Engineering Research, 1961, 6, 169.

16. M. Aghbashlo, M.H. Kianmehr, S. Khani, M. Ghasemi, International Agrophysics, 2009, 23, 313.

17. A. Midilli, H. Kucuk, Z. Yapar, Drying Technology, 2002, 20, 1503.

18. I. Alibas, Journal of Agricultural Sciences, 2012, 18, 43.

19. H. Darvishi, M. Azadbakht, A. Rezaeiasl, A. Farhang, Journal of the Saudi Society of Agricultural Sciences, 2013, 12, 121.

20. M.R. Okos, G. Narsimhan, R.K. Singh, A.C. Weitnauer, "Food Dehydration in Handbook of Food Engineering", Edited by Heldman D. R. and Lund D. B. Marcel Dekker Inc., 1992.

21. R.A. Chayjan, M. Kaveh, S. Khayati, Food Measure, 2017, 11, 12.

22. E. Mirzaee, S. Rafiee, A. Keyhani, Z. Emam-Djomeh, Research in Agricultural Engineering, 2009, 55, 114. 
